Enrico Brugnoli ${ }^{1}$, Olga Solomina ${ }^{2 *}$, Luciano Spaccino ${ }^{1}$, Ekaterina Dolgova ${ }^{2}$

${ }^{1}$ Institute of Agro-environmental Biology and Forestry (IBAF), Via Marconi 2, 05010

Porano, (TR), Italy; e-mail: enrico.brugnoli@por.ibaf.cnr.it

${ }^{2}$ Institute of Geography RAS, Moscow, Staromonetny-29, IGRAS, 119017 Russia;

*Corresponding Author e-mail: olgasolomina@yandex.ru

\title{
CLIMATE SIGNAL IN THE RING WIDTH, DENSITY AND CARBON STABLE ISOTOPES IN PINE (PINUS SILVESTRIS L.) IN CENTRAL CAUCASUS
}

\begin{abstract}
Variability of width, maximum density and stable isotopes $\left(\boldsymbol{\delta}^{13} \mathrm{C}\right)$ in tree-rings of Scots pine (Pinus sylvestris L.) were studied in Northern Caucasus. Statistically sufficient agreements between ring width chronologies allow to construct composite chronology for the Elbrus area. Absence or low correlation between indices of the ring width and maximum density chronology point out different climatic signal. The influence of temperature and precipitation on these tree-ring parameters was also analyzed. The ring width of pine at the upper tree limit in the Baksan valley correlates positively with the June and July precipitation $(r=0.3 ; 0.3 ; 0.4, p<0.05)$. No correlation with temperature parameters was found. The maximum density reflects the warm period temperature (April-October). The similarity in interannual variations of $\delta^{13} \mathrm{C}$ in annual rings between the individual samples means that their display a coherent common signal. This signal can be largely interpreted as the June and July precipitation.
\end{abstract}

KEY WORDS: Scots pine, stable isotopes $\left(\delta^{13} \mathrm{C}\right)$, tree-ring width, tree-ring maximum density, Northern Caucasus

\section{INTRODUCTION}

The longest continuous time series of meteorological observations in Caucasus slightly exceed a century. Those located at the high elevation are only half century long or even shorter. In order to better predict the decadal and interannual climatic variations in this region it is important to extend the time series in the past. In the areas, where the growth of annual rings in trees closely associates with some of the climatic parameters, this problem can be at least partly solved basing on the dendrochronological approach.

Tree-ring formation consists of three stages: cell division, cell enlargement and cell-wall thickening [Thomas, 1991]. Wood properties are determined over time by various factors during tracheid development. Earlywood formation depends mainly on growth reserves from the preceding growing season, while latewood formation depends on photosynthetic production and net $\mathrm{CO}_{2}$ assimilation during the current growing season. Thus, all the seasonal and annual temperatures and precipitation may influence tree-ring development (cambial cell division, radial growth and lignification).

In this paper we report the results of the study of climatic signal in pine tree rings in Caucasus. As soon as different parameters of the annual rings often reflect different climatic forcings we analyzed the total wing width, early and late wood ring width, maximum density and stable isotopes $\left(\delta^{13} \mathrm{C}\right)$ in pine (Pinus silvestris $\mathrm{L}$.) in Central Caucasus at the vicinity of the upper tree limit and report here our first results. 


\section{STUDY AREA AND STATE-OF-THE-ART}

The Caucasus Mountains are located on the south of the East European Plain between the Black Sea in the west and Caspian Sea in the East. The tree-ring sites analyzed in this study are situated in the western and central part of the Greater Caucasus in Baksan and Teberda valleys at the elevation of 2200-2500 m asl.

In general, climate of the region is defined by the complex topography and prevailed westerly wind. In winter atmospheric circulation over the Greater Caucasus is dominated by extensions of the Icelandic depression from the west and the Siberian high from the east. In summer extensions of the Azores high prevail. Annual precipitation declines from over $2000 \mathrm{~mm}$ in the western Caucasus to less than $200 \mathrm{~mm}$ in the east. The western and central sectors of northern slope of the Greater Caucasus, where the study area is located, are in particular characterized by a strong convective activity in summer. Precipitation maxima occur in July-September in response to convective activity triggered by a combination of strong insolation and depressions developing on the Polar front and enhanced by the orographic uplift [Shahgedanova, 2002].

The pine (Pinus silvestris L.) forests are broadly distributed in the region. The upper tree limit of pine rises up to $3000 \mathrm{~m}$ asl. Some pine trees at in the vicinity of the upper timberline exceed theage of 400-500years. The attempts to reconstruct climatic changes in Caucasus using the width of annual rings have been undertaken repeatedly since the 1960s (see review by Solomina [1999]). So far none of these was successful, because the ring width here is influenced by many simultaneously acting factors and the correlation between individual meteorological parameters and tree-ring width indices was found to be weak or statistically insignificant. For example Turmanina [1979] found out that the ring width of the pines growing on the southern slope of the Baksan River valley increases during the humid and warm summers and decreases during the summers with the low temperatures.

\section{MATERIALS AND METHODS. CHRONOLOGIES.}

To construct and analyze the ring width chronologies we used the standard procedures of measuring, cross-dating and indexation routinely used in tree-ring analysis [Stokes, 1968]. Two cores per tree were collected. They were sanded by progressively finer paper to obtain more contrast between ring boundaries. Then we used LINTAB ver. 3.0 system with a resolution of $0.01 \mathrm{~mm}$ [Rinn, 1996] and TSAP software to measure ring width and graphical presentations of the results. Some sites are located quite close to each other and represent the same climate conditions. Thus to enhance the sample depth of ring-width chronologies we have combined sites CHS and CHE into one called CHS and KHAT and KHTP into one entitled KHTP (Table 1).

To develop maximum density chronology (MaxD) we used 46 cores of pine from two sites (KHAT and KHTP) located at the upper tree limit (2300-2400 $\mathrm{m}$ a.s.l.) in the valley of the Teberda River. For densitometry analyses the resins must be extracted first. The samples were treated by Soxhlet apparatus with solution of ethanol and toluene during 6 hours, then 2 hours of pure ethanol [Schweingruber, 1988]. To make wood surface flat and delete any curvature appeared due to dryness the microtome was used. After that cores were scanned by flat-bed scanner with high resolution of 1000 dpi. Scanned images were processed using commercially available software LignoVision (Rinntech) to obtain brightness profile of the reflected light images as a substitution of the regular densitometry. This routine was done in the Laboratory of Tree-Ring Research (Tucson, Arizona) in 2009. In this paper we use the term "maximum density" although X-ray densitometry wasn't applied. This approach was advocated earlier [e.g. McCarroll, Pettigrew, and Luckman, 2002].

The cross-dating procedure was validated by using COFECHA software [Holmes, 1983] and core segments with low correlation values were excluded from the analysis. Each 
Table 1. List of samples in Caucasus

\begin{tabular}{|c|c|c|c|c|c|c|c|}
\hline Sites & Location & $\mathrm{N}$ & $E$ & $\mathrm{H}$ & $\begin{array}{c}\text { Number } \\
\text { of samples } \\
\text { (trees) }\end{array}$ & $\begin{array}{l}\text { Date of } \\
\text { collection }\end{array}$ & $\begin{array}{c}\text { Age for two } \\
\text { or more } \\
\text { series }\end{array}$ \\
\hline KV & $\begin{array}{l}\text { B. Azau, at the MSU } \\
\text { station (moraine 14th } \\
\text { century) }\end{array}$ & $\begin{array}{c}4315 \\
951\end{array}$ & $\begin{array}{c}4228 \\
847\end{array}$ & 2200 & $8(4)$ & $\begin{array}{c}2002 \\
\text { August, } \\
\text { September }\end{array}$ & 1653-2002 \\
\hline GAR & $\begin{array}{l}\text { Forefield of Garabashi } \\
\text { glacier }\end{array}$ & $\begin{array}{c}4315 \\
965\end{array}$ & $\begin{array}{c}4229 \\
201\end{array}$ & 2340 & $13(7)$ & 2003 June & 1697-2002 \\
\hline $\mathrm{CHS}$ & $\begin{array}{l}\text { Southern slope of } \\
\text { Cheget mt. }\end{array}$ & $\begin{array}{c}4315 \\
977\end{array}$ & $\begin{array}{c}4229 \\
199\end{array}$ & 2470 & $8(4)$ & 2003 June & $1765-2002$ \\
\hline $\mathrm{CHE}$ & $\begin{array}{l}\text { Eastern slope of } \\
\text { Cheget mt. }\end{array}$ & $\begin{array}{c}4314 \\
478\end{array}$ & $\begin{array}{c}4230 \\
773\end{array}$ & 2535 & $7(4)$ & 2003 June & 1860-2002 \\
\hline$B A Z$ & $\begin{array}{l}\text { Forefield of B. Azau } \\
\text { glacier, terminal } \\
\text { moraine }\end{array}$ & $\begin{array}{c}4326 \\
660\end{array}$ & $\begin{array}{c}4246 \\
272\end{array}$ & 2420 & $18(11)$ & $\begin{array}{c}2004 \\
\text { September }\end{array}$ & 1684-2004 \\
\hline KHAT & $\begin{array}{l}\text { Valley of Malaya } \\
\text { Khatipara river (right } \\
\text { valley side) }\end{array}$ & $\begin{array}{l}4325 \\
815\end{array}$ & $\begin{array}{c}4142 \\
513\end{array}$ & 2285 & $24(12)$ & 3 June 2006 & 1779-2005 \\
\hline KHTP & $\begin{array}{l}\text { Valley of Malaya } \\
\text { Khatipara river (left } \\
\text { valley side) }\end{array}$ & $\begin{array}{c}4326 \\
835\end{array}$ & $\begin{array}{c}4142 \\
339\end{array}$ & 2394 & $22(11)$ & 2 June 2006 & 1709-2005 \\
\hline SOF & $\begin{array}{l}\text { Valley of Psysh river } \\
\text { (moraine) }\end{array}$ & $\begin{array}{c}4327 \\
060\end{array}$ & $\begin{array}{c}4116 \\
592\end{array}$ & 2022 & $14(7)$ & $\begin{array}{l}16 \text { August } \\
2007\end{array}$ & 1720-2006 \\
\hline $\mathrm{KYZ}$ & $\begin{array}{l}\text { Valley of Kyzgych river } \\
\text { (upper tree-limit) }\end{array}$ & $\begin{array}{c}4325 \\
680\end{array}$ & $\begin{array}{c}4118 \\
212\end{array}$ & 2392 & $13(7)$ & $\begin{array}{l}17 \text { August } \\
2007\end{array}$ & 1578-2006 \\
\hline
\end{tabular}

tree-ring series contain biological trends associated with tree-age. To remove the trend and preserve variations related to climate we standardized tree-ring series to dimensionless indices using the program ARSTAN [Cook, 1985]. Tree-ring series were standardized by fitting either a negative exponential curve or line with negative slope or horizontal line to each series and ring-width indices generated by division. Resulting site chronologies were developed by averaging the indices from the each treering series by using a bi-weight robust mean [Cook, 1990]. The composite chronology was developed by the indices averaging.

Our ring width pine chronologies cover at the moment the period AD 1550-2009 and o ne ring width density chronology at the Khatipara site in Teberda valley covers AD 1800-2005 (Figs. 1-2, Table 1). For the stable isotopes $\left(\delta^{13} \mathrm{C}\right)$ analyses we extracted wood from three disks of pine trees killed by the avalanche on 29 December 2001 in the vicinity of the Research Station of the Moscow State University (LAV site, samples 11, 23 and
26) (Fig. 3). The site is located in Baksan valley at the edge of the Garabashi debris flow cone. The wood that we extracted from 50 annual rings (1960-1999) contains both early and late wood portions, although due to the larger early wood rings this one dominates in the samples. We also measured separately the early and late wood ring width for the samples processed for the $\delta^{13} \mathrm{C}$ analyses.

Whole wood (i.e., earlywood and latewood) from each single tree-ring was ground using a Retsch mill (Mixer Mills, MM 200, Haan, Germany).The resulting powderwas weighed (approximately $1.5 \mathrm{mg}$ ) in tin capsules. Tree ring isotopic ratio was determined by combustion of the samples in an elemental analyzer (Carlo Erba, model NA 1500, Milan, Italy) coupled to an isotopic ratio mass spectrometer (ISOPRIME, Isoprime Limited, Cheadle, UK). Analysis precision was greater than $\pm 0.03 \%$ o. The results were expressed as $\delta^{13} \mathrm{C}$ in \%o relative to the international standard VPDB [Brugnoli and Farquhar, 2000] according to $\left.\delta^{13} \mathrm{C}=\left(\mathrm{R}_{\text {sample }} / \mathrm{R}_{\text {standard }}-1\right) \times 1000\right]$, where $R_{\text {sample }}$ and $R_{\text {standard }}$ represent the ${ }^{13} \mathrm{C} /{ }^{12} \mathrm{C}$ 

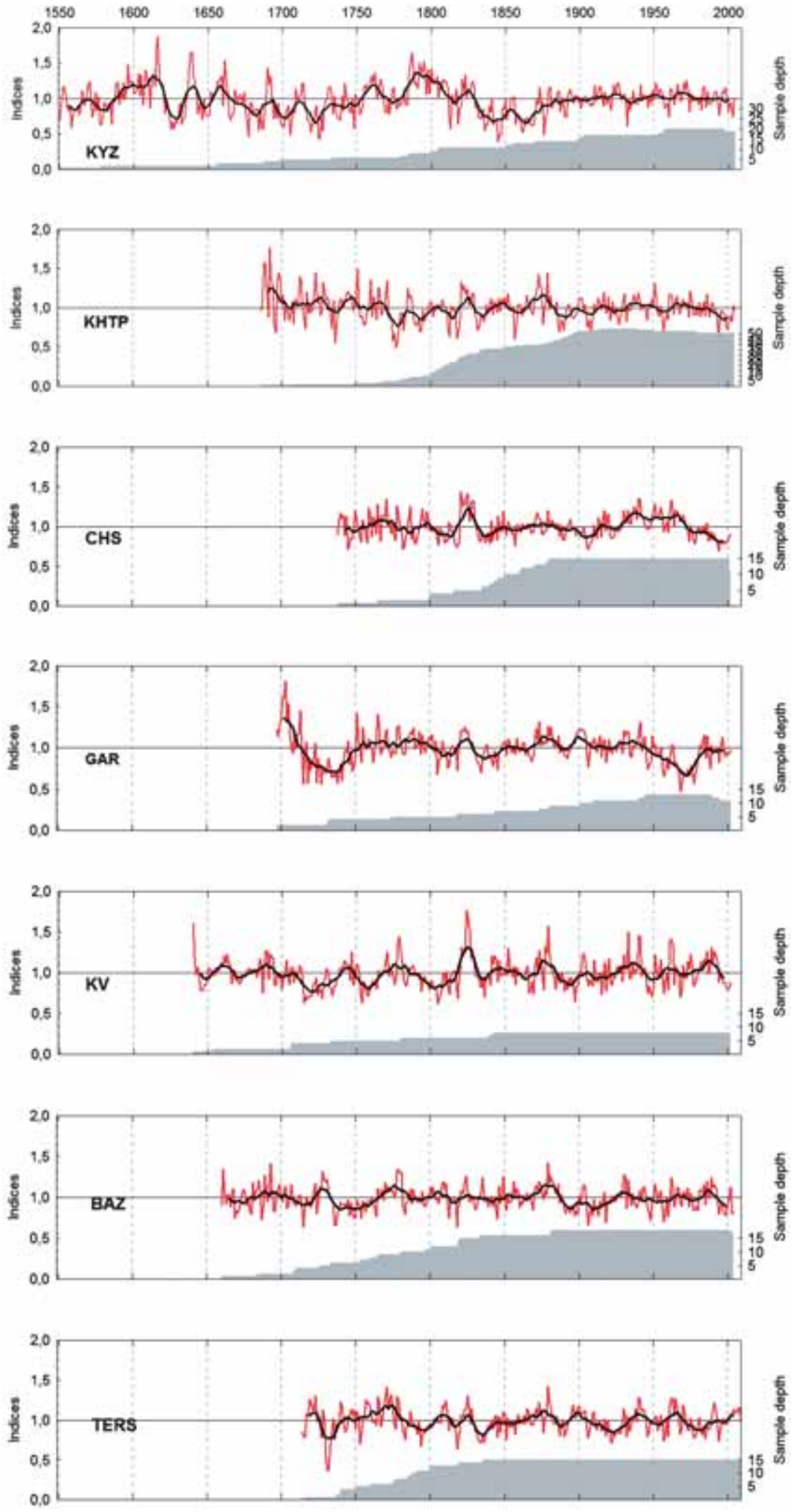

Fig. 1. Pine ring width chronologies in Caucasus (Baksan, Teberda and Kyzgich valleys). Gray fields - samples depth 

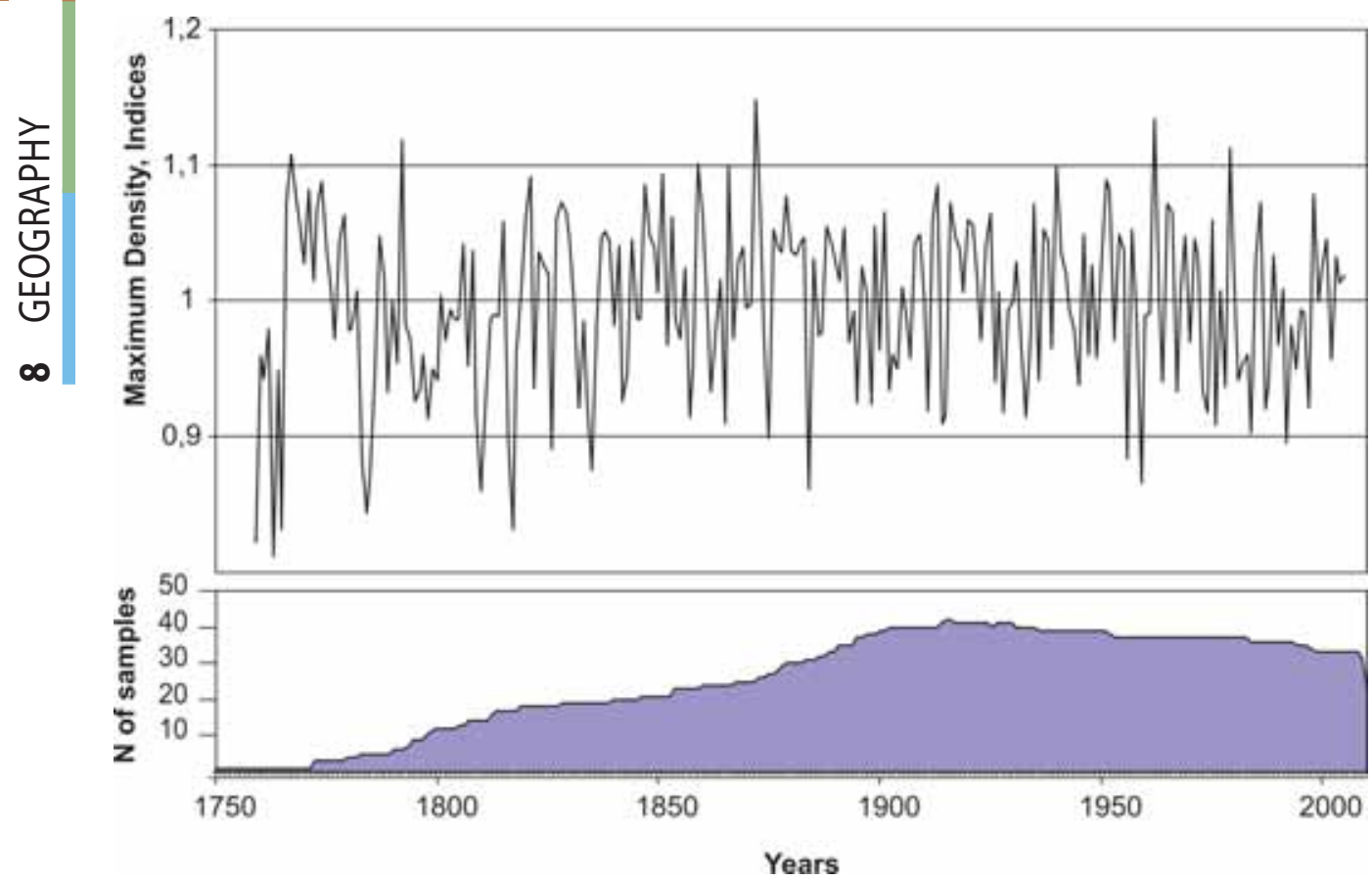

Fig. 2. Maximum density pine chronology in Teberda valley

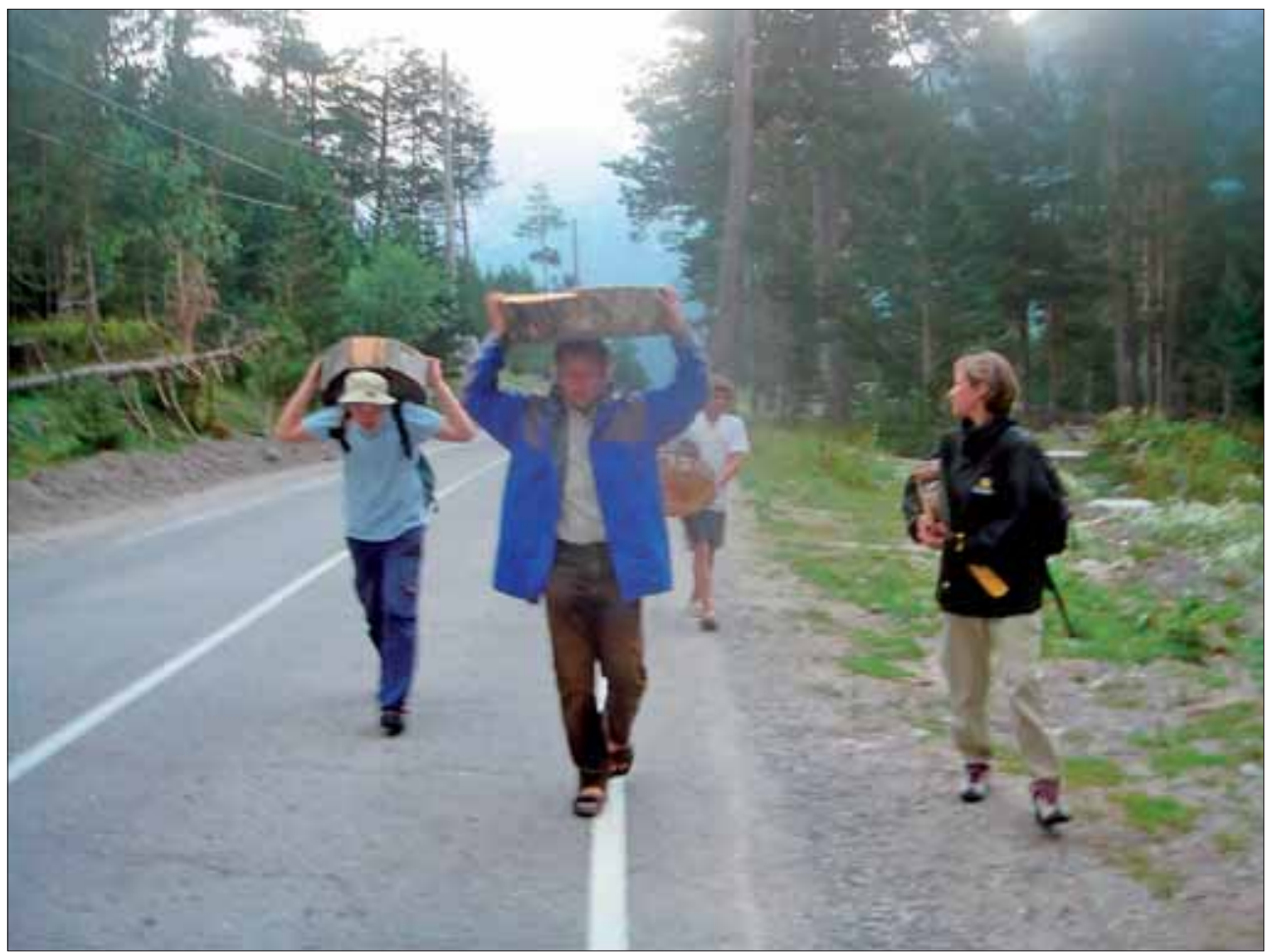

Fig. 3. Pine trees killed and damaged by the avalanche in 2001 sampled for the analyses of stable isotopes 
Table 2. Correlation coefficients of the 7 standard chronologies. Marked values significant at $p<0.05$

\begin{tabular}{|l|c|c|c|c|c|c|c|c|}
\hline Chronology & KYZ & KHTP & CHS & GAR & KV & BAZ & TERS & MaxD \\
\hline KYZ & 1.00 & 0.41 & 0.33 & 0.23 & 0.25 & 0.32 & 0.39 & -0.02 \\
KHTP & & 1.00 & 0.64 & 0.42 & 0.58 & 0.53 & 0.63 & 0.23 \\
CHS & & & 1.00 & 0.36 & 0.57 & 0.41 & 0.53 & 0.30 \\
GAR & & & & 1.00 & 0.50 & 0.45 & 0.48 & 0.11 \\
KV & & & & & 1.00 & 0.57 & 0.55 & 0.10 \\
BAZ & & & & & & 1.00 & 0.53 & -0.03 \\
TERS & & & & & & & 1.00 & 0.12 \\
MaxD & & & & & & & & 1.00 \\
\hline
\end{tabular}

molar ratios of the sample and the standard, respectively. An internal standard consisting of a C3 sucrose with a $\delta^{13} \mathrm{C}=-25.08 \%$ was analyzed periodically every ten samples to check the accuracy of analysis.

In order to explain the climatic forcing for different annual ring parameters (width, density and stable isotopes) we correlated these time series with the monthly temperature and precipitation measured at the nearest meteorological stations (Terskol, Severny Klukhor, Teberda).

The individual ring width samples as well as local chronologies cross-date and intercorrelate very well (Table 2). This correlation allowed the construction of the composite chronology for the Elbrus area. Most of ring width chronologies do not correlate with the maximum density, which is a sign of different climatic signal embedded in the two tree ring parameters.

\section{RESULTS}

\section{Ring width and density}

Table 3 shows the correlation of the pine ring width of the composite Elbrus chronology and maximum density chronology with monthly temperature and precipitation. The coefficients

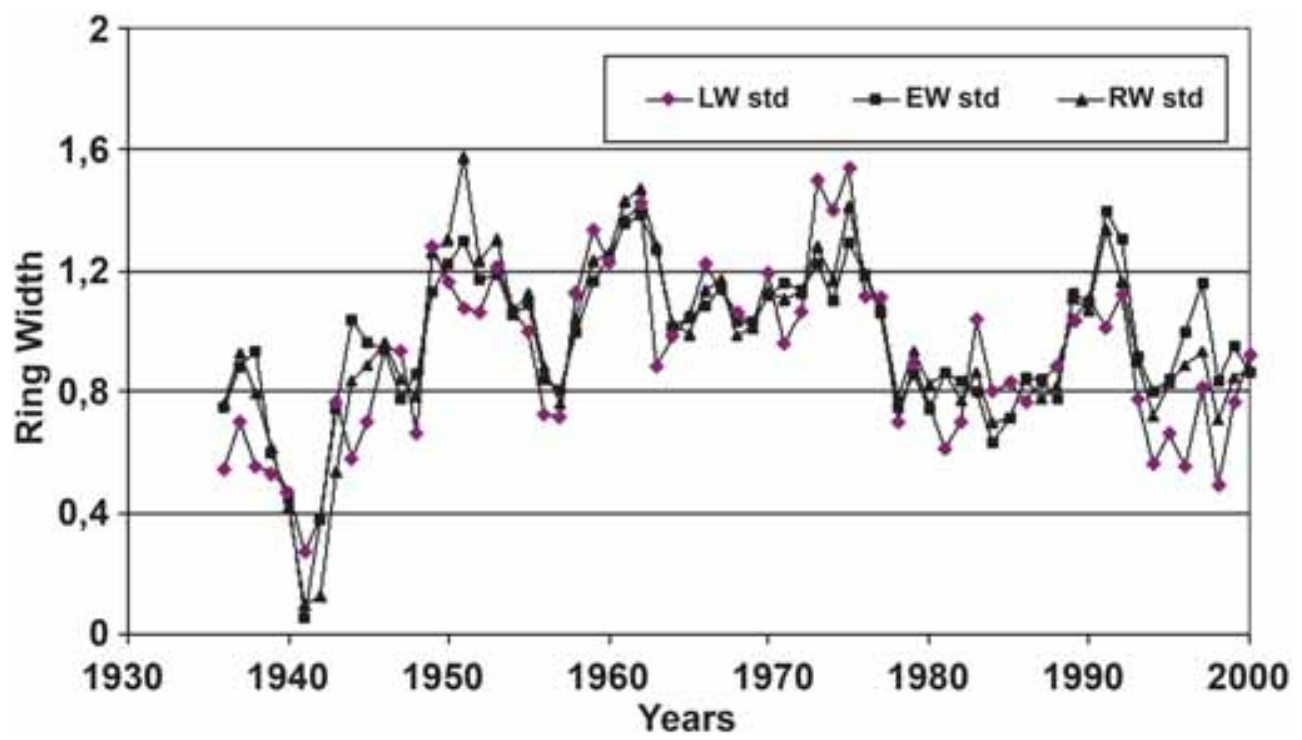

Fig. 4. Early (EW), late (LW) and total (RW) ring width measurements averaged for three samples used for the stable isotope analyses 
of correlation for the ring width (below the lines) show no statistical significance with climatic parameters except for the cases: positive correlation can be seen with precipitation in June at the Severnyi Klukhor meteorological station $(r=0.3, p<0.05)$, in July $(r=0.3, p<$ 0.05 ) at the Teberda met station and in July $(r=0.4, p<0.05)$ at the Terskol station. The numbers above the lines in the table 3 display a systematic positive significant correlation of the maximum density with the spring-summer temperatures measured at different meteorological stations. Due to this significant and sustainable correlation the April-October temperature values at the Severnyi Klukhor meteorological station and the maximum density we were able to reconstruct this parameter for the last 200 years [Dolgova, Solomina, 2010].

\section{Stable isotopes}

The total ring widths of three samples used for the isotope analyses cross-date well against each other and versus the composite Elbrus chronology. It means that the three selected samples represent adequately the whole regional data set. The measurements of the early and late wood ring width of these three samples show that the early and late wood ring width are very closely correlated. They also agree quite well with the total ring width (Fig. 4).

The correlation of monthly mean temperature and precipitation of Terskol meteorological station located in the vicinity of the sampling site with the early, late and total wood ring width show that all three parameters responded similarly to the climate changes. This result is not surprising taking into consideration the similarity of the ring width curves. Namely they showed a significant negative correlation with September temperature, a negative correlation with the precipitation in April and a positive one with the precipitation in July (Fig. 5). The composite pine chronology in this region positively correlates with June precipitation, i.e. our smaller data set generally shows a similar reaction to climate. Fig. 6 shows a very good agreement 
between the $\delta^{13} \mathrm{C}$ variations in the three analyzed samples both in terms of high frequency variations and the long-term negative trend observed since 1980s (the last one except for the sample LAV 23) (see also Table 4).

The mean $\delta^{13} \mathrm{C}$ LAV chronology correlates positively (although weakly) with the summer temperature sensitive maximum density, and the late ring width chronologies (Table 4).
A significant positive correlation is found for the $\delta^{13} \mathrm{C}$ chronology and November temperature (Fig. 7). The same parameter correlates significantly with the total ring width of the regional chronology and the maximum density chronology and seems to be very important for the pine growth in these conditions. The warm November may extend the growing season and therefore stimulate more successful growth of woody plants at high elevation stands. The most prominent signal detected for the $\delta^{13} \mathrm{C}$

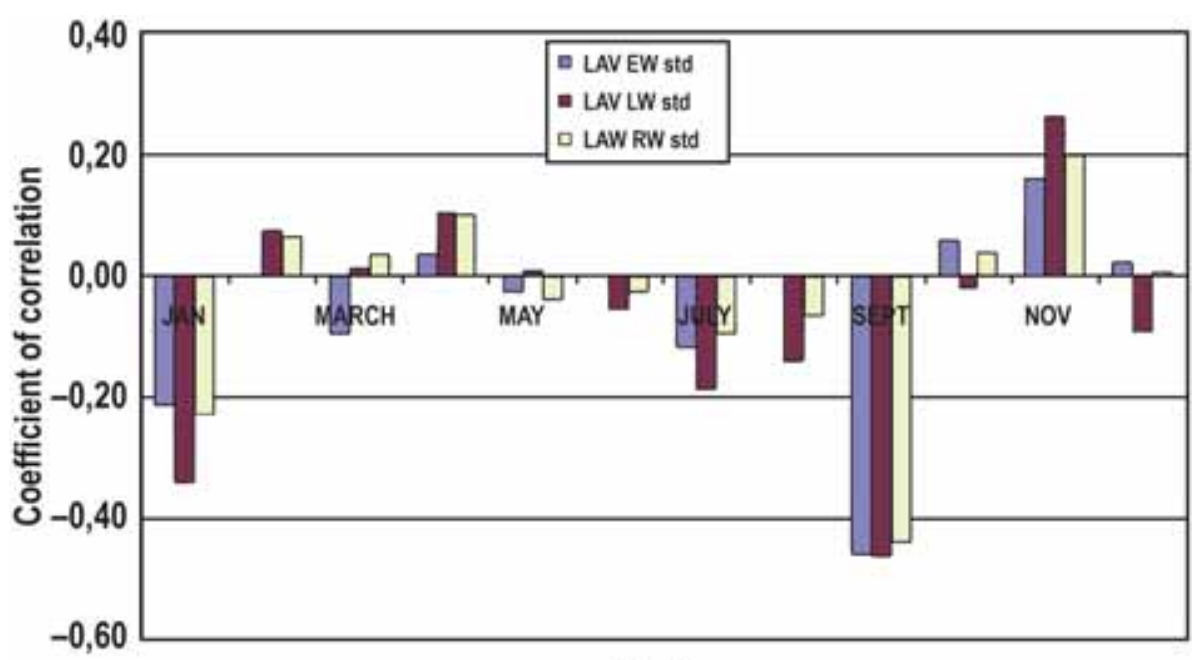

Months

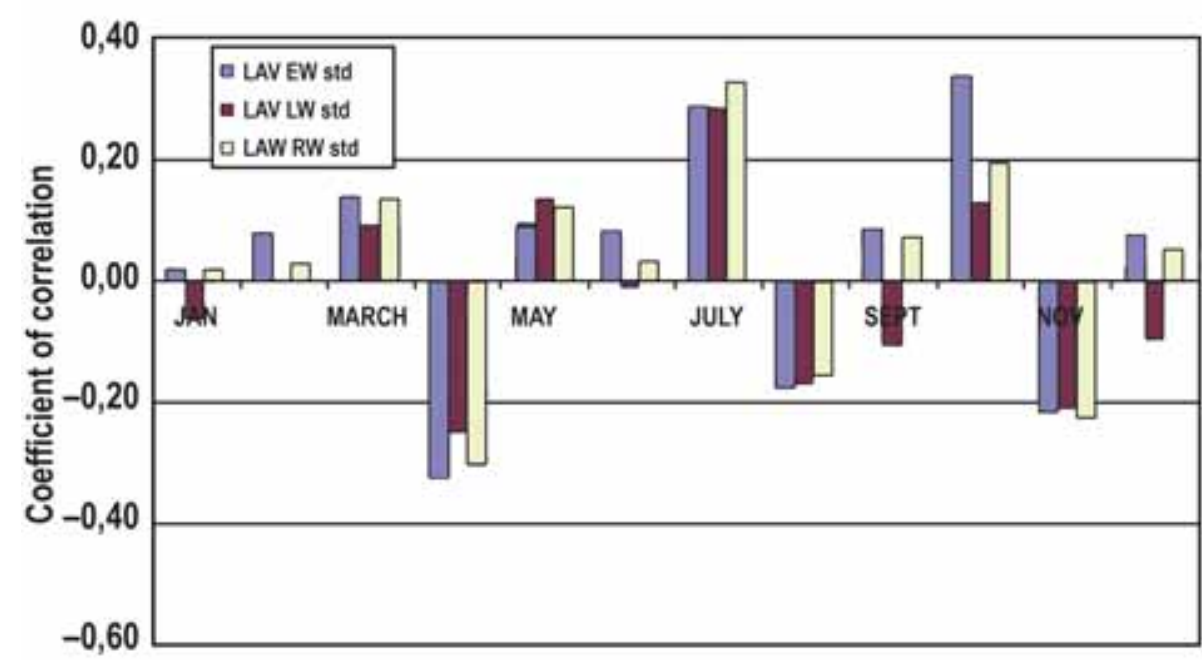

Months

Fig. 5. Temperature (A) and precipitation (B) signals in the ring width of three pine samples for early, late and total ring width of pine used for the isotope analyses 
Table 4. Correlation of ring width, maximum density and $\delta 13 \mathrm{C}$ chronologies. Marked values significant at $p<0.01$

\begin{tabular}{|c|c|c|c|c|c|}
\hline & MaxD & $\delta 13 C$ mean & LW std & EW std & RW std \\
\hline $\operatorname{MaxD}$ & 1,00 & & & & \\
\hline$\delta 13 C$ mean & 0,35 & 1,00 & & & \\
\hline LW std & 0,08 & 0,30 & 1,00 & & \\
\hline EW std & 0,11 & 0,14 & 0,71 & 1,00 & \\
\hline RW std & 0,17 & 0,19 & 0,84 & 0,94 & 1,00 \\
\hline
\end{tabular}

chronology is the negative correlation with June and July precipitation. It is well known that the pine growth in Central Caucasus is partly limited by moisture availability [Turmanina, 1979] (see Fig. 5B). The correlation of different chronologies (width, density, isotope composition) with the same parameters (e.g. November temperature, July precipitation) may be explained by a common signal. However our analysis shows that the three types of the chronologies that we used are significantly different: they are forced by different climatic parameters and reflect different seasonality.

\section{DISCUSSION}

The climatic signal in the ring widthand maximum density was discussed many times in special dendrochronological literature [e.g. Fritts, 1976, Schweingruber, 1988, Gagen, D. McCarroll, 2004]. Here we concentrate on some examples of the detection of the climatic signal in the ${ }^{13} \mathrm{C} /{ }^{12} \mathrm{C}$ series of pine in different ecological conditions.

In general the stable carbon isotope chronologies have been established from tree rings to detect the fluctuations in ${ }^{13} \mathrm{C} /{ }^{12} \mathrm{C}$ ratios of atmospheric $\mathrm{CO}_{2}$ or as a means for reconstructing past climates [Stuiver 1978; Leavitt and Long 1988, Carroll and

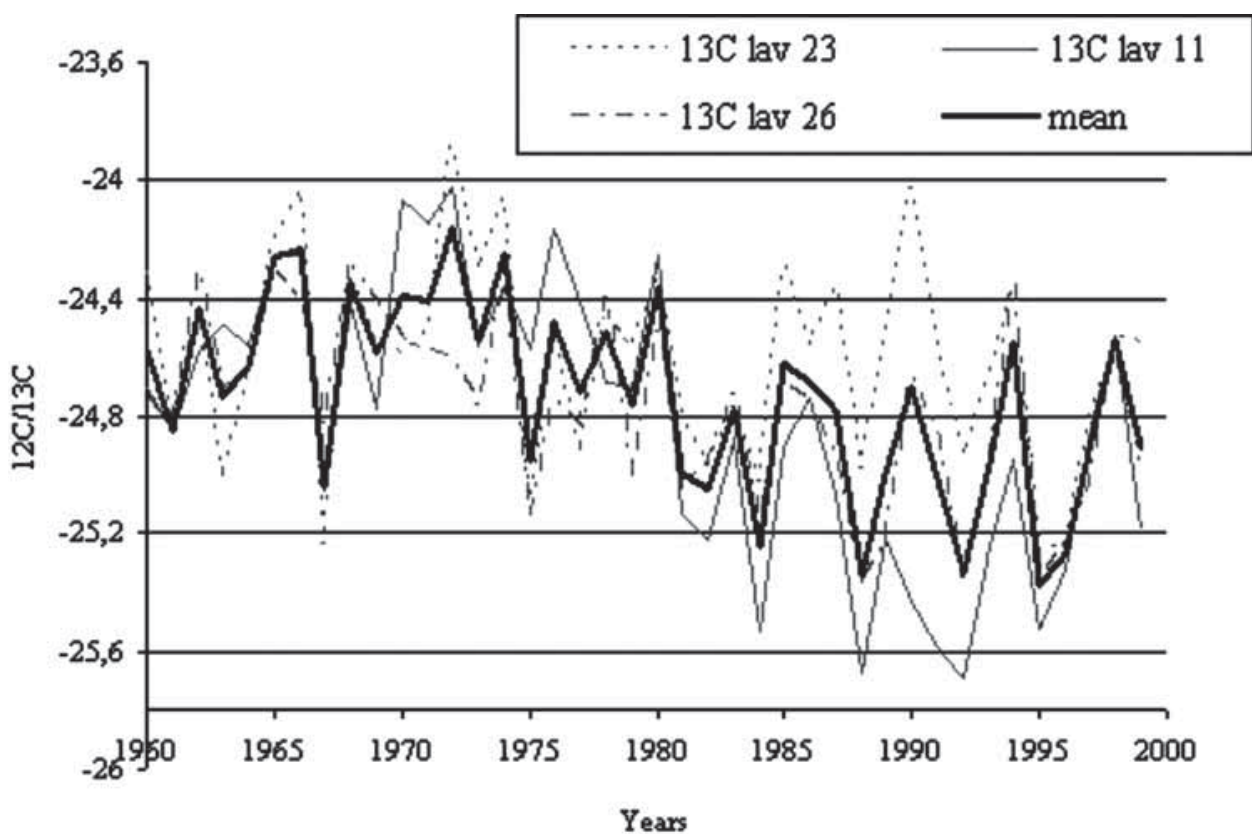

Fig. 6. Variation in $\delta^{13} \mathrm{C}$ in three samples of pine (site LAV) in Baksan valley and their averaged values 
Loader, 2004]. Stable carbon isotopes record the balance between stomatal conductance and photosynthetic rate, dominated at dry sites by relative humidity and soil water status and at moist sites by summer irradiance and temperature [Carrol and Loader, 2004; Brugnoli and Farquhar, 2000]. In our case the carbon isotope composition in pine tree rings clearly depends on moisture stress and soil water availability. Low precipitation during the period of June-July likely induces stomatal closure and a decrease in the ratio of chloroplastic to atmospheric $\mathrm{CO}_{2}$ concentrations which, in turn, causes an increase in $\delta^{13} \mathrm{C}$.

Lewitt [1993] found a moisture stress signal in the $\delta^{13} \mathrm{C}$ pine (Pinus edulis) in North America. Liu et al. [1996] identified correlation with the MayJune precipitation for the Pinus tabilaeformis in Northern China. In Northern Finland the signal in the Scots pine (P.silvestris) was very site specific [MC Caroll and Pawelck, 2001], while Waterhouse et al.
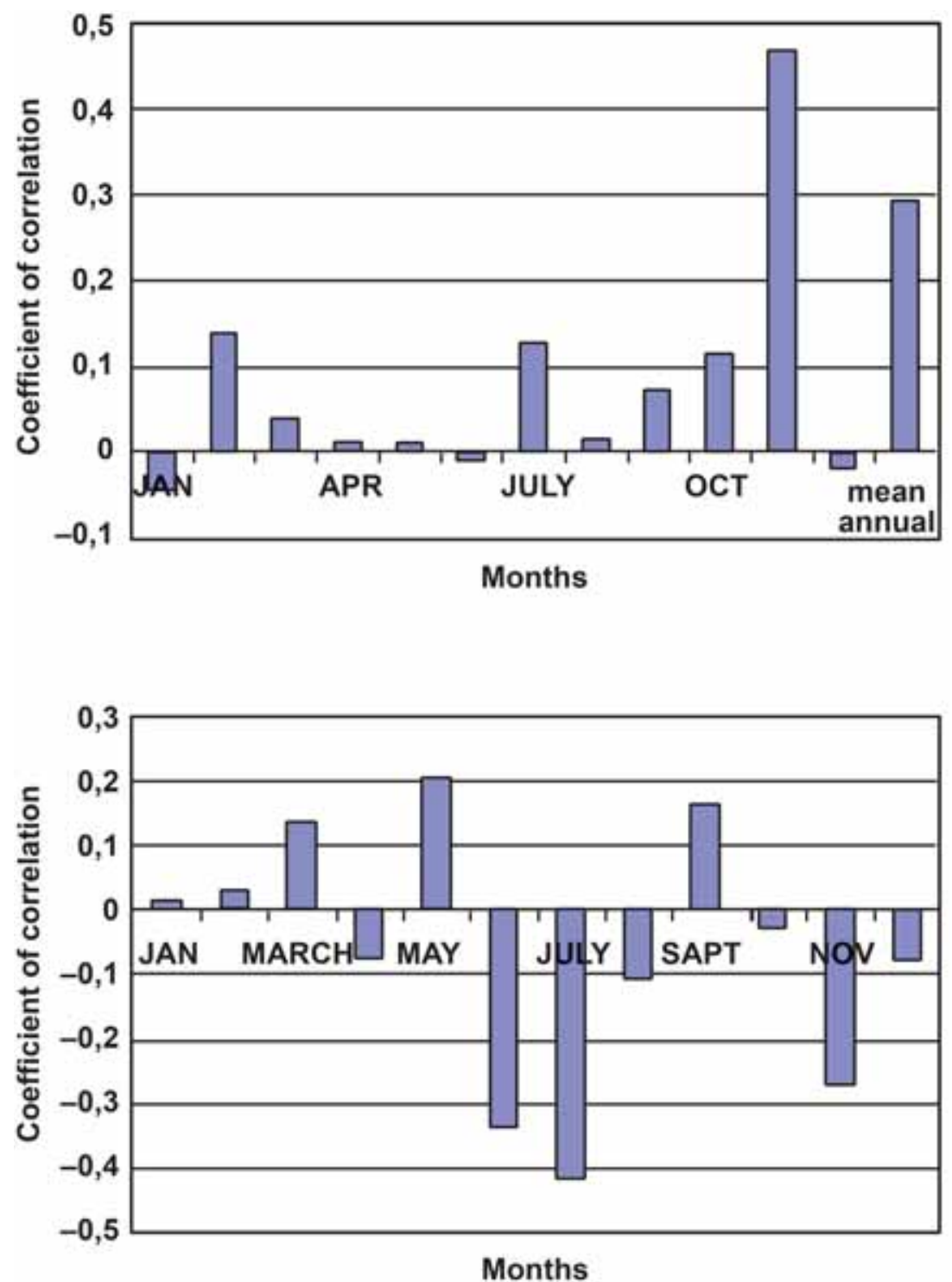

Fig. 7. Response function and correlation coefficients between the $\delta^{13} \mathrm{C}$ chronology and monthly temperature (A) and precipitation (B) at Terskol meteorological station 
[2004] found a correlation of 3-year smoothed $\delta^{13} \mathrm{C}$ pine (P. silvestris) chronology with the flow of $\mathrm{Ob}$ river reflecting the moisture stress. Feng and Epstein [1995] discovered that the high frequency $\delta^{13} \mathrm{C}$ variability in pine, juniper and oak in North America correlates with the precipitation while the long term changes are coherent with the atmospheric $\mathrm{CO}_{2}{ }^{13} \mathrm{C}$ composition and its decrease due to the effect of ${ }^{13} \mathrm{C}$ dilution by fossil fuel combustion.

Our findings generally agree with those studies reporting the dependence of the $\delta^{13} \mathrm{C}$ fluctuations in pine annual rings upon the drought stress and precipitation of the warm period. The closest results, i.e. the negative correlation between $\delta^{13} \mathrm{C}$ of pine chronology and the summer precipitation was previously reported for the French Alps [Gagen, McCarroll, 2004] - a region which is quite similar by its climatic and environmental conditions to the Central and Western Caucasus.

Our research demonstrated that the high elevation pine vegetation in the Central Caucasus is a very promising climatic proxy. Different parameters of the pine rings can be used as predictors for the reconstruction of various climatic variables: the maximum density correlates with the warm period thermal conditions while the $\delta^{13} \mathrm{C}$ largely reflects the moisture stress.

\section{CONCLUSIONS}

1. The ring width of pine at the upper tree limit in the Baksan valley correlates positively with the June-July precipitation. No correlation with temperature parameters except for the month of November is found.

2. The maximum density proved to be more clearly related to climatic parameters, namely it reflects the warm period temperature (April-October). The correlation is high enough to be used for the modeling and reconstruction of this parameter.

3. The similarity in the interannual variations of $\delta^{13} \mathrm{C}$ in annual rings between the individual samples means that they display a coherent common signal. This signal can be largely interpreted as the June and July precipitation.

\section{REFERENCES}

1. Brugnoli, E., Farquhar, G.D. (2000). Photosynthetic fractionation of carbon isotopes. In: Photosynthesis Physiology and Metabolism, Advances in Photosynthesis, eds R.C. Leegood, T.D. Sharkey and S. von Caemmerer, Kluwer Academic Publishers, the Netherlands, pp. 399-434.

2. Cook E.R. (1985). A time series analysis approach to tree ring standardization // Ph. D. dissertation. University of Arizona, Tucson, AZ. 171.

3. Cook E.R., Kairiukstis L.A. (1990). Methods of dendrochronology. Applications in the Enviromental Sciences. Dordrecht; Boston, London, Kluwer Acad. Publ.

4. Dolgova E., Solomina O. (2010). The first quantitative reconstruction of warm period temperature in Caucasus according to the tree-ring data. Doklady of Academy of Sciecnes. 431, № 2, p. 1-5. (in Russian).

5. Feng X. and Epstein S. (1995). Climatic trends from isotopic records of tree rings: The past 100-200 years. Climatic Change. Volume 33, Number 4, 551-562, DOI: 10.1007/ BF00141704.

6. Gagen, M., McCarroll, D. (2004). Latewood Width, Maximum Density, and Stable Carbon Isotope Ratios of Pine as Climate Indicators in a Dry Subalpine Environment, French Alps Arctic, Antarctic, and Alpine Research, Vol. 36, No. 2, pp. 166-171. 
7. Leavitt, S., and Long, A. (1988). Stable carbon isotope chronologies from trees in the southwestern United States. Global Biochemical Cycles 2 (3), 189-198.

8. Leavitt, S.W. (1993). Environmental information from 13C/12C ratios of wood. Geophysical Monographs 78, 325-331.

9. Liu, Y., Wu, X., Leavitt, S.W., Hughes, M.K. (1996). Stable carbon isotope in tree rings from Huangling, China and climatic variation. Science in China D (39) 2, 152-161.

10. Leavitt, S., and Long, A. (1988). Stable carbon isotope chronologies from trees in the southwestern United States. Global Biochemical Cycles 2 (3), 189-198.

11. McCarroll D., Loader N.J. (2004). Stable isotopes in tree rings. Quaternary Science Reviews, $23,771-801$

12. McCarroll, D., Pawellek, F. (2001). Stable carbon isotope ratios of Pinus sylvestris from northern Finland and the potential for extracting a climate signal from long Fennoscandian chronologies. The Holocene 11, 517-526.

13. McCarroll, D. Pettigrew, E. and Luckman A. (2002). Blue Reflectance Provides a Surrogatefor Latewood Density of High-latitude Pine Tree Rings Arctic, Antarctic, and Alpine Research, Vol. 34, No. 4, pp. 450-453.

14. McNulty, S. G., and Swank. W. T. (1995). Wood (delta)^(13) C as a Measure of Annual Basal Area Growth and Soil Water Stress in a Pinus Strobus Forest. Ecology 76:1581-1586. [doi:10.2307/1938159]

15. Schweingruber F.H. (1988). Tree rings: basics and applications of dendrochronology. Dordrecht, Holland, RPC.

16. Shahgedanova, M. (2002). The Physical geography of Northern Eurasia, Oxford University Press. 571.

17. Solomina, O.N. (1999). Mountain glaciation of Northern Eurasia in Holocene. Moscow, Nauchny Mir. 264 pp. (in Russian).

18. Stokes M.A., Smiley T.L. (1968). An introduction to tree-ring dating. Tucson, The University of Arizona Press.

19. Stuiver, M. (1978). Atmospheric carbon dioxide and carbon reservoir changes. Science 199, 253-258.

20. Thomas, R.J. (1991). Wood: formation and morphology. In Lewin, M. and Goldstein, I.S., editors, Wood structure and composition, New York: Marcel Dekker Inc.

21. Turmanina V.I. (1979). Dendrochronology of avalanches in the upperstream of Baksan valley valleys. Rhythms of Glacial Processes. Mosc. Gos. Univ., Moscow, pp. 128-134. (in Russian).

22. Waterhouse, J.S., Barker, A.C., Carter, A.H.C., Agafonov, L.I., Loader, N.J. (2000). Stable carbon isotopes in Scots pine tree rings preserve a record of the flow of the river Ob. Geophysical Research Letters 27, 3529-3532. 
Dr. Enrico Brugnoli - research leader of the Plant Physiological Ecology and Stable Isotope laboratory of the Institute of Agro-environmental and Forest Biology (IBAF). Director of IBAF Institute since 2008 he has a long experience in plant physiological ecology and he has published more that hundred papers in refereed Journal and several book chapters.

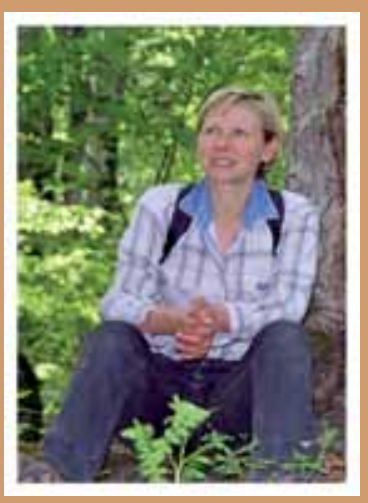

Dr. Olga Solomina - expert in paleoclimatology, glacier variations and tree-ring based reconstructions in the high mountains, the Arctic and Antarctic, author of more than 150 scientific publications. Deputy Director of Institute of Geography RAS, Corresponding Member of RAS.

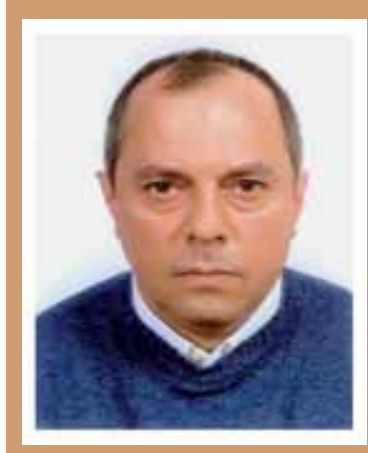

Luciano Spaccino - laboratory technical manager of the stable isotope laboratory of the Institute of Agro-environmental and Forest Biology (IBAF). He is employed at IBAF since 1990 and he has more than twenty year experience in instable isotope mass spectrometry, gas chromatography and GC-IRMS.

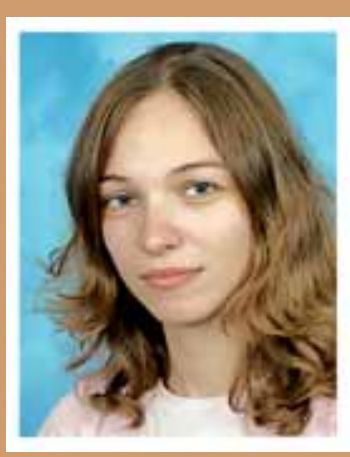

Ekateruna Dolgova - research scientist at the Glaciological Department of the Institute of Geography RAS, expert in tree-ring analyses. Focuses on the ring width density in the Caucasus. 